\title{
PENGANGKATAN ANAK MENURUT HUKUM ISLAM
}

\author{
Oleh: \\ Haedah Faradz \\ Fakultas Hukum Universitas Jenderal Soedirman Purwokerto
}

\begin{abstract}
During the time application of child become power of district court very Islam. Law number 3 year 2006 concerning change of law number 7 year 1989 concerning Islamic court, giving power to justice of religion to accept, to checking, and judging and also of child genesis and lifting of child pursuant to law of Islam. Stipulating of lifting of child pursuant to Islamic law by justice of religion do not decide contractual terms or lineage relation / link with old fellow contain him. foster child judicially remain to confess as child contain from old fellow contain him. Foster child in law of Islam nor make that foster child as child contain or likened by the child him and rights of like child contain and illegal foster parent become sponsor do woman foster child marry.
\end{abstract}

Kata Kunci : adopsi, Hukum Islam

\section{A. Pendahuluan}

Keinginan mempunyai anak bagi setiap pasangan suami isteri merupakan naluri insani dan secara fitrah anak-anak tersebut merupakan amanah Allah SWT kepada suami isteri tersebut. Bagi orang tua, anak tersebut di harapkan dapat mengangkat derajat dan martabat orang tua, kelak apabila dewasa. Fakta menunjukan bahwa tidak sedikit perkawinan yang dibangun dengan susah payah pada akhirnya bubar karena kemelut rumah tangga yang disebabkan karena tidak mempunyai keturunan.

Sebagai makhluk sosial keluarga merupakan kelompok masyarakat terkecil, yang terdiri atas seorang ayah, ibu, dan anak. Akan tetapi tidak selalu ketiga unsur itu terpenuhi, sehingga kadang-kadang terdapat suatu keluarga yang tidak mempunyai anak, karena alasan tersebut maka pasangan tersebut mengadopsi anak.

Pengangkatan anak adalah suatu perbuatan hukum yang mengalihkan seseorang anak dari lingkungan kekuasaan keluarga orang tua yang sah/walinya yang sah/orang lain yang bertanggung jawab atas perawatan, pendidikan dan membesarkan anak tersebut, ke dalam lingkungan kekuasaan keluarga orang tua ang- kat berdasarkan putusan/penetapan Pengadilan Negeri. ${ }^{1}$

Sifat perbuatan pengangkatan anak merupakan perbuatan hukum yang tidak dapat dianggap hanya sebagai hasil kesepakatan antara para pihak semata, pengangkatan anak harus dianggap sebagai suatu lembaga yang menciptakan suatu hubungan hukum yang sah bagi anak angkat dengan lingkungan keluarga orang tua angkat berdasarkan penetapan pengadilan. Hendaknya dipahami bahwa perbuatan pengangkatan anak bukanlah suatu perbuatan hukum yang dapat terjadi pada suatu saat seperti halnya dengan penyerahan barang, melainkan merupakan suatu rangkaian kejadian hubungan kekeluargaan yang menunjukan adanya kesungguhan, cinta kasih dan kesadaran yang penuh akan segala akibat dari pengangkatan anak.

Terjadinya pengangkatan anak seperti yang berlaku dalam tradisi barat dimana status anak berubah menjadi seperti anak kandung, tidak dibenarkan menurut hukum Islam. Dalam bidang kemasyarakatan atau muamalah Hukum Islam itu berkembang menurut kepentingan masyarakat dengan berdasarkan pada Al-Qur'an dan sunah Rasul. Hukum Islam adalah hukum yang dibuat untuk kemaslahatan hidup manusia

\footnotetext{
1 Erna Sofwan Sjukrie, 1992, Lembaga Pengangkatan Anak, Mahkamah Agung RI, hlm. 17
} 
dan oleh karenanya Hukum Islam sudah seharusnya mampu memberikan jalan keluar dan petunjuk terhadap kehidupan manusia baik dalam bentuk sebagai jawaban, terhadap suatu persoalan yang muncul maupun dalam bentuk aturan, yang dibuat untuk menata kehidupan manusia itu sendiri. Hukum Islam dituntut untuk dapat menjawab persoalan yang muncul sejalan dengan perkem-bangan dan perubahan yang terjadi di masyarakat, oleh karena Hukum Islam hidup di tengah-tengah masyarakat. Masyarakat senantiasa mengalami perubahan, maka Hukum Islam perlu dan bahkan harus mempertimbangkan perubahan yang terjadi di masyarakat tersebut. Hal ini perlu dilakukan agar Hukum Islam mampu mewujudkan kemaslahatan dalam setiap aspek kehidupan manusia, di segala tempat dan waktu. Dalam teori Hukum Islam kebiasaan dalam masyarakat dapat dijadikan sebagai hukum baru selama kebiasaan tersebut sejalan dengan prinsipprinsip ajaran Islam, termasuk pula dalam hal pengangkatan anak. Pengangkatan anak dalam Islam sama sekali tidak merubah hukum, nasab, dan mahram antara anak angkat dan orang tua angkatnya. Perubahan yang terjadi dalam Pengadilan Agama menurut Hukum Islam adalah perpindahan tanggung jawab pemelihara-an pengawasan dari orang tua asli kepada orang tua angkat, hanya merubah status anak angkat menjadi anak kandung.

Dalam rangka memenuhi kebutuhan masyarakat, pembuat UU RI memberi peluang pengangkatan anak berdasarkan Hukum Islam melalui Pengadilan Agama. Menguatnya keinginan masyarakat beragama Islam untuk mengangkat anak berdasarkan Hukum Islam, menyebabkan tidak terbendungnya keinginan mereka untuk mengajukan permohonan pengangkatan anak di Pengadilan Agama sebagai salah satu lembaga pelaksana kekuasaan kehakiman bagi rakyat pencari keadilan yang beragama Islam. Masyarakat umumnya telah mengenal apa yang disebut lembaga adopsi yaitu suatu pengangkatan anak orang lain menjadi anak kandung orang tua angkat dengan hak-hak dan kewajiban sebagaimana hak-hak dan kewajiban yang dimiliki anak kandung.
Lembaga adopsi tersebut pernah dilakukan oleh Nabi Muhammad SAW, yakni ketika beliau mengangkat anak yang bernama Zaid bin Haritsah, tetapi oleh masyarakat jahiliyah pada masa itu Zaid bin Haritsah tersebut dipanggil Zaid bin Muhammad, karena memang hukum pengangkatan anak pada saat itu membawa konsekuensi akibat hukum dinasabkannya anak angkat ke dalam nasab orang tua angkatnya. Surat AL- Ahzab ayat 5, yang meluruskan konsepsi adopsi tersebut dengan menyatakan" Panggilah mereka (anak-anak angkat) itu dengan tetap memakai nama bapak-bapak mereka, itulah yang lebih adil pada sisi Allah", maka kemudian Zaid dipanggil oleh masyarakat saat itu menjadi Zaid bin Haritsah. ${ }^{2}$ Selama ini perkara permohonan pengangkatan anak menjadi kewenangan absolut Pengadilan Negeri, untuk itu maka masyarakat yang beragama Islam menuntut melalui Lembaga Legislatif agar diberi saluran hukum untuk mengajukan permohonan pengangkatan anak berdasarkan hukum Islam, maka pada tanggal 20 april 2006 lahirlah UU No. 3 tahun 2006 Tentang Perubahan atas UU No. 7 tahun 1989 Tentang Peradilan Agama yang memberikan kewenangan kepada Pengadilan Agama untuk menerima, memeriksa dan mengadili serta menyelesaikan perkara berdasarkan Hukum Islam, yang sesuai dengan asas personalita keislaman yang tunduk dan yang dapat ditundukkan kepada kekuasaan lingkungan peradilan agama, hanya mereka yang mengaku pemeluk agama Islam.

Penganut agama lain di luar Islam atau yang non Islam, tidak tunduk dan tidak dapat dipaksa tunduk kepada kekuasaan lingkungan Peradilan Agama. Asas personalita keislaman diatur dalam Pasal 49 huruf a angka 20 tahun 2006 yang menyatakan peradilan agama bertugas dan berwenang memeriksa, memutus, dan menyelesaikan perkara di tingkat pertama, antara orang-orang yang beragama Islam perkawinan, kewarisan, wasiat, hibah, wakaf, dan shodaqah ada perubahan tentang penetapan asal usul anak dan penetapan pengangkatan

\footnotetext{
2 Fauzan, 2007, Perbedaan mendasar akibat hukum penetapan pengangkatan anak, Varia Peradilan, Varia Peradilan NO 256 edisi Maret 2007, hlm. 32
} 
anak berdasarkan hukum Islam. Penetapan dari Pengadilan Agama akan menjadi dasar bagi Kantor Catatan Sipil untuk mengeluarkan akta kelahiran anak bagi yang memerlukan.

Berdasarkan uraian di atas, maka tulisan ini dimaksudkan untuk menjelaskan tentang bentuk pengangkatan anak yang dibolehkan menurut Hukum Islam.

\section{B. Pembahasan}

Pengangkatan anak di Indonesia telah menjadi kebutuhan masyarakat dan menjadi bagian dari sistem hukum kekeluargaan, oleh karena itu lembaga pengangkat anak yang telah menjadi bagian masyarakat akan mengikuti perkembangan situasi dan kondisi.

Pengertian pengangkatan anak berkembang di Indonesia sebagai terjemahan dari bahasa Inggris "Adoption" yang berarti mengangkat seorang anak, anak orang lain untuk dijadikan sebagai anak sendiri dan memiliki hak yang sama dengan anak kandung ${ }^{3}$. Pada saat Islam disampaikan oleh Nabi Muhammad SAW kepada masyarakat arab (zaman jahiliyah) Lembaga Pengangkatan Anak telah menjadi tradisi dengan istilah "Tabani" yang berarti mengambil anak angkat ${ }^{4}$. Sedangkan dalam kamus besar Bahasa Indonesia istilah Pengangkatan anak disebut juga dengan istilah adopsi yang berarti pengambilan (pengangkatan) anak orang lain secara sah menjadi anak sendiri. Pengadilan Agama (adopsi, tabani) yaitu suatu pengangkatan orang lain sebagai anak sendiri, anak yang diadopsi disebut anak angkat, peristiwa hukumnya disebut pengangkatan anak. Agama Islam tidak melarang pengangkatan anak, asalkan pengangkatan anak untuk tujuan pemeliharaan, pendidikan dan pembiayaan kehidupan si anak. Tegasnya Agama Islam melarang pengangkatan anak untuk meneruskan keturunan, dijadikan seperti anak kandung.
AL-Qur'an Surat AL-Ahzab ayat 4 dan 5 menegaskan hal ini yang terjemahanya adalah sebagai berikut ${ }^{5}$

".... Dia tidak menjadikan anak-anak angkatmu sebagai anak kandungmu (sendiri). Yang demikian itu hanyalah perkataanmu di mulut saja. Dan Allah mengatakan yang sebenarnya dan dia menunjukkan jalan yang benar.

"Panggillah mereka (anak-anak angkat) dengan memakai nama bapak-bapak mereka, itulah yang lebih adil pada Sisi Allah dan jika kamu tidak mengetahui bapak-bapak mereka, maka panggillah mereka sebagai saudara-saudaramu seagama, dan tidak ada dosa atasmu terhadap apa yang kamu khilaf padanya, tetapi yang ada dosanya apa yang disengaja oleh hatimu.

Dalam kajian Hukum Islam, ada dua pengertian pengangkatan anak ${ }^{6}$.

1. mengambil anak orang lain untuk diasuh dan dididik dengan penuh perhatian dan kasih sayang, tanpa diberikan status anak kandung, kepadanya cuma ia diperlakukan oleh orang tua angkatnya sebagai anak sendiri.

2. mengambil anak orang lain sebagai anak sendiri dan ia diberi status sebagai anak kandung, sehingga ia berhak memakai nama keturunan (nasab) orang tua angkatnya dan saling mewarisi harta peninggalan, serta hak-hak orang lain sebagai akibat hukum antara anak angkat dan orang tua angkat.

Dari ketentuan di atas, penulis dapat mengambil kesimpulan bahwa pengertian nomor satu adalah yang lebih sesuai dengan pengangkatan anak yang dilandasi menurut Hukum Islam, karena, tujuan pengangkatan anak hanya untuk mendidik, merawat, memberikan kasih sayang dan menyekolahkan dengan harapan anak tersebut terangkat derajatnya baik secara moril maupun materiil.

Secara faktual pengadilan agama telah menjadi bagian dari masyarakat muslim di Indonesia. Sebelum terbentuknya Undang-

\footnotetext{
5 Rachmad Budiono, 1999, Pembahasan Hukum Kewarisan Islam di Indonesia, Bandung : Citra Aditya Bakti, hlm. 192

6 Nasroen Haron dkk, 1996, Ensiklopedi hukum Islam, Jakarta : PT Ichtiar Baru Van Hoeve, hlm. 29
}

\footnotetext{
3 Simorangkir, 1987, Kamus Hukum, Jakarta, hlm. 4

${ }^{4}$ Fauzan, op.cit, hlm. 37
} 
Undang yang mengatur secara khusus, pemerintah mengeluarkan Instruksi Presiden No. 1 tahun 1991 tentang penyebarluasan Kompilasi Hukum Islam. Pada Pasal 171 huruf h, secara definitif disebutkan bahwa anak angkat adalah anak yang dalam pemeliharaan untuk hidupnya sehari-hari, biaya pendidikan disebut beralih tanggung jawabnya dari oarng tua asal kepada orang tua angkatnya berdasarkan putusan pengadilan. Definisi anak angkat dalam Kompilasi Hukum Islam tersebut, jika diperbandingkan dengan definisi anak angkat dalam UndangUndang No. 23 Tahun 2002 Tentang Perlindungan Anak, memiliki kesaman substansi. Pasal 1 angka 9 menyebutkan bahwa anak angkat adalah anak yang haknya dialihkan dari lingkungan kekuasaan keluarga orang tua, wali yang sah, atau orang lain yang bertanggung jawab atas perawatan, pendidikan, dan membesarkan anak tersebut, kedalam lingkungan keluarga orang tua angkatnya berdasarkan putusan atau penetapan pengadilan.

Menurut Masbuk Zuhdi mengatakan bahwa adopsi seperti praktik dan tradisi di zaman jahiliyah, yang memberi status kepada anak angkat sama dengan status anak kandung tidak dibenarkan (dilarang) dan tidak diakui oleh Islam. Hubungan anak angkat dengan orang tua angkat dan keluarganya tetap seperti sebelum diadopsi, yang tidak mempengaruhi kemahraman dan kewarisan ${ }^{7}$.

Menyantuni orang miskin, memelihara anak yatim piatu merupakan beberapa bidang ajaran utama dalam agama Islam. Akan tetapi hukum kekeluargaan tidak dapat dikesampingkan. Mengangkat anak disesuaikan dengan tujuan-tujuan ajaran agama Islam, tentu saja diperkenankan. Memberikan status hukum kepada anak angkat sama dengan anak kandung merupakan perbuatan yang bertentangan dengan Hukum Islam. Contohnya seorang laki-laki yang meng-angkat anak perempuan, tetap tidak dapat bertindak sebagai wali dalam pernikahan anak angkatnya demikian juga dalam bidang kewarisan.

7 Ibid, hlm. 192
Menurut Hukum Islam pengangkatan anak hanya dapat dibenarkan kalau memenuhi ketentuan-ketentuan sebagai berikut:

1. tidak memutuskan hubungan darah antara anak yang diangkat dengan orang tua biologis dan keluarga.

2. anak angkat tidak berkedudukan sebagai ahli waris dari orang tua angkat, melainkan tetap sebagai ahli waris dari orang tua kandungnya, demikian juga orang tua angkat tidak berhak berkedudukan sebagai pewaris dari anak angkatnya.

3. anak angkat tidak boleh mempergunakan nama orang tua angkatnya secara langsung, kecuali sekedar sebagai tanda pengenal/ alamat.

4. orang tua angkat tidak dapat bertindak sebagai wali dalam perkawinan terhadap anak angkatnya ${ }^{8}$.

Pasal 209 ayat (2) KHI menyatakan bahwa anak angkat hanya berhak mendapat wasiat wajibah, sebanyak-banyak sepertiga dari harta warisan". Lembaga wasiat wajibah merupakan bagian dari kajian wasiat pada umumnya. Persoalan wasiat wajibah sangat relevan dengan kajian hukum pengangkatan anak (tabanni) dalam Hukum Islam, karena salah satu akibat dari peristiwa hukum pengangkatan anak adalah timbulnya hak wasiat wajibah antara anak angkat dan orang tua angkatnya. ${ }^{10}$

Pengangkatan anak dalam istilah Arab disebut tabani atau tabani ath-thifl, yaitu menjadikan seseorang sebagai anak. Al-Qur'an menyebutnya da'iyyun, yaitu menghubungkan asal-usul kepada seseorang yang bukan ayah kandungnya. Menurut Al-Qur'an, da'-iyyun adalah klaim yang tidak benar terhadap asal-usul karena seseorang telah menghubungkan keturunan kepada yang bukan keturunannya.

Al-Imam Al-Lausi juga menyatakan bahwa haram hukumnya bagi orang yang dengan sengaja menasabkan ayah kepada yang bukan

\footnotetext{
8 Muderis Zaini, 1995, Adopsi Tinjauan dari Tiga Sistem Hukum, Jakarta : Sinar Grafika, hlm. 54

9 Ribyal Ka'bah, Pengangkatan anak dalam UU No. 3 Th 2006, Varia Peradilan No. 248 edisi juli 2006, hlm. 32

10 Ahmad Kamil \& M. Fauzan, 2008, Hukum Perlindungan dan Pengangkatan anak di Indonesia, Raja Jakarta : Grafindo Persada, hlm. 125
} 
ayahnya. Unsur kesengajaan menasabkan seseorang kepada seorang ayah yang bukan ayahnya padahal ia mengetahui ayahnya yang sebenarnya, adalah penyebab haramnya perbuatan tsb, tetapi mengambil dan merawat anak yang terlantar tanpa harus memutus nasab orang tua kandungnya adalah wajib hukumnya ${ }^{11}$.

Dari uraian di atas dapat disimpulkan bahwa memungut, mengasuh, memelihara, dan mendidik anak-anak yang terlantar demi kepentingan dan kemaslahatan anak dengan tidak memutuskan nasab orang tua kandungnya adalah perbuatan terpuji dan dianjurkan oleh agama Islam, bahkan dalam kondisi tertentu dimana tidak ada orang lain yang memeliharanya maka bagi yang mampu yang menemukan anak terlantar hukumnya wajib untuk mengambil dan memeliharanya tanpa harus memutuskan hubungan nasab dengan orang tua kandungnya.

Sebelum lahirnya UU No. 3 Tahun 2006 Tentang Perubahan atas UU No. 7 Tahun 1989 Tentang Peradilan Agama, pertimbanganpertimbangan pengangkatan anak menurut Hukum Islam yaitu

1. Islam memperbolehkan pengengkatan anak dengan tujuan memelihara kepentingan anak.

2. Pengangkatan anak dalam Islam sebenarnya hanya peralihan tanggung jawab pemeliharaan biaya hidup, pendidikan, bimbingan agama dan lain-lain dari orang tua asal kepada orang tua angkat, tetapi tidak memutus hubungan hukum atau nasab dengan orang tua asalnya.

3. Antara anak angkat dan orang tua angkat terdapat hubungan keperdataan washiah wajibah.

4. Untuk pengangkatan anak diperlukan persetujuan orang tua asal wali atau badan hukum yang menguasai anak yang akan diangkat.

Pengangkatan anak menurut Hukum Islam sebenarnya merupakan hukum Hadhonah/ pemeliharaan anak yang diperluas dan sama sekali tidak merubah hubungan hukum, nasab

\footnotetext{
11 Zakaria Ahmad, 1977, Ahkam ai Aulad bi al Islam, Jakarta : Bulan Bintang, hlm. 35
}

dan mahram antara anak angkat dengan orang tua dan keluarga asalnya.

Dalam Hukum Islam pemeliharaan anak disebutkan dengan Al Hudhinah yang merupakan kata dari Al Hadhanah yang berarti mengasuh atau memelihara bayi. Dalam pengertian istilah Hadhanah adalah pemeliharaan anak yang belum mampu berdiri sendiri, biaya pendidikannya dan pemeliharaannya dari segala yang membahayakan jiwanya. Hadhanah sama sekali tidak ada hubungannya dengan perwalian terhadap anak, baik itu yang menyangkut perkawinan maupun yang menyangkut hartanya. Hadhanah tersebut adalah semata-mata tentang perkara anak dalam arti mendidik dan mengasuhnya. ${ }^{12}$

Masalah Hadhanah merupakan hal yang sangat penting untuk dilaksanakan, oleh karena itu orang yang melaksanakan Hadhanah itu haruslah memenuhi syarat-syarat tertentu yaitu:

1. Berakal sehat

2. Dewasa

3. Mempunyai kemampuan dan keahlian

4. Amanah dan berbudi luhur

5. Beragama Islam

6. Merdeka/bukan budak

Perubahan yang terjadi hanya perpindahan tanggung jawab pemeliharaan, pengawasan dan pendidikan dari orang tua asli kepada orang tua angkat. Pengangkatan anak tersebut tidak merubah status anak angkat menjadi anak kandung dan status orang tua angkat menjadi status orang tua kandung. Hanya dalam praktik pengangkatan anak yang sering terjadi di masyarakat dengan cara dibuat seperti anak kandung pada waktu orang tua angkat membuat akta kelahiran. Oleh karena itu, tidak bisa diandaikan seolah-olah anak angkat itu sebagai anak yang baru lahir di tengah-tengah keluarga orang tua angkatnya seperti anak kandung. Penetapan pengangkatan anak berdasarkan Hukum Islam oleh Pengadilan Agama tidak memutuskan hubung-an hukum atau hubungan nasab dengan orang tua kandungnya. Penetap-

\footnotetext{
${ }^{12}$ Abdul Manan, 2003, Aneka Masalah Hukum Material dalam Praktek Peradilan Agama, Jakarta : Pustaka Bangsa, hlm. 78
} 
an pengadilan agama hanya sebagai dasar bagi Kantor Catatan Sipil untuk membuat akta kelahiran.

Ada beberapa hal yang harus diperhatikan dalam penetapan anak angkat tersebut. Pertama, anak angkat tidak dapat menggunakan nama ayah angkatnya, seperti dijelaskan oleh ayat 5 Surah AL-Ahzab. Kedua, antara ayah angkat dengan anak angkat, ibu angkat dan saudara angkat tidak mempunyai hubungan darah. Mereka dapat tinggal serumah, tetapi harus menjaga ketentuan mahram dalam Hukum Islam, antara lain tidak dibolehkan melihat aurat, berkhalwat/bercinta, ayah atau saudara angkat tidak menjadi wali perkawinan untuk anak angkat perempuan dan lain-lain. Ketiga, di antara mereka tidak saling mewarisi.

Para ulama fiqih sepakat menyatakan bahwa Hukum Islam melarang praktik pengangkatan anak yang memiliki implikasi yuridis, seperti pengangkatan anak yang dikenal oleh hukum barat/hukum sekuler dan pada msyarakat jahiliyah. ${ }^{13}$ Hukum Islam hanya mengakui pengangkatan anak dalam pengertian beralihnya kewajiban untuk memberikan nafkah sehari-hari, mendidik, memelihara, dan lain-lain. Dalam konteks beribadah kepada Allah SWT. Hukum Islam menghargai hukum adat sepanjang tidak bertentangan dengan prinsip-prinsip Hukum Islam, bahkan menempatkannya sebagai bagian dari sumber hukum Islam al-'adah almuhakamah. Masyarakat hukum adat telah mengenal pengambilan anak dari suatu keluarga untuk dijadikan anak yang diasuh dengan penuh kasih sayang layaknya anak sendiri, dengan bermacam-macam istilah, seperti anak kukut, anak pupon, anak akon. ${ }^{14}$

Aspek hukum menasabkan anak angkat kepada orang tua angkatnya atau yang memutuskan hubungan nasab dengan orang tuanya untuk kemudian dimasukkan ke dalam klan nasab orang tua angkatnya, adalah yang paling mendapat kritikan dari Islam karena sangat bertentangan dengan ajaran Islam.

\section{Penutup}

Penetapan pengangkatan anak berdasarkan Hukum Islam oleh Pengadilan Agama tidak memutuskan hubungan hukum atau hubungan nasab dengen orang tua kandungnya. Anak angkat dalam Hukum Islam juga tidak menjadikan anak angkat itu sebagai anak kandung atau anak yang dipersamakan hak-hak dengan kewajibannya seperti anak kandung. Hubungan hukum antara anak angkat dengan orang tua angkatnya seperti hubungan anak asuh, yang dididik dengan penuh perhatian dan kasih sayang tanpa diberikan status sebagai anak kandung.

Orang tua angkat hanya berkewajiban dalam pemeliharaaan nafkah dan pendidikan. Anak angkat dapat memperoleh harta warisan orang rua angkatnya melalui wasiat hajibah.

\section{Daftar Pustaka}

Ahmad, Zakaria. 1997. Ahkam al Aulad bi al Islam. Jakarta: Bulan Bintang;

Budiono, Rachmad. 1999. Pembaharuan Hukum Kewarisan Islam di Indonesia. Bandung: Citra Aditya Bakti;

Fauzan. 2007. Perbedaan Mendasar Akibat Hukum Penetapan Pengangkatan Anak. Jakarta, Varia Peradilan No. 256 edisi Maret;

Haron, Nasroun. 1996. Ensiklopedi Hukum Islam. Jakarta: Ichtiar Baru Van Hoeve;

Ka'bah, Rifyal. Pengangkatan Anak dalam UU No. 3 tahun 2006. Jakarta: Varia Peradilan No 248 edisi Juli 2006;

Kamil, Ahmad dkk; 2008; Hukum Perlindungan dan Pengangkatan Anak di Indonesia; Jakarta: Raja Grafindo Persada;

Manan, Abdul. 2003. Aneka Masalah Hukum Materil dalam Praktik Peradilan Agama. Jakarta, Pustaka Bangsa;

Sofwan, Erna Sjukrie. 1992. Lembaga Pengangkatan Anak. Jakarta: Mahkamah Agung;

Zaini, Mudris. 1995. Adopsi Tinjauan dari Tiga Sistem Hukum. Jakarta: Sinar Grafika.

\footnotetext{
${ }^{13}$ Ahmad Kamil, op. cit, hlm. 113

${ }^{14} \mathrm{Ibid}, \mathrm{hlm} .106$
} 
